\title{
Trade creation and diversion: effects of EU enlargement on agricultural and food products and selected Asian countries
}

\section{Bruna Zolin \& Utai Uprasen}

\section{Asia Europe Journal}

Studies on Common Policy Challenges

ISSN 1610-2932

Asia Eur J

DOI 10.1007/s10308-018-0508-7

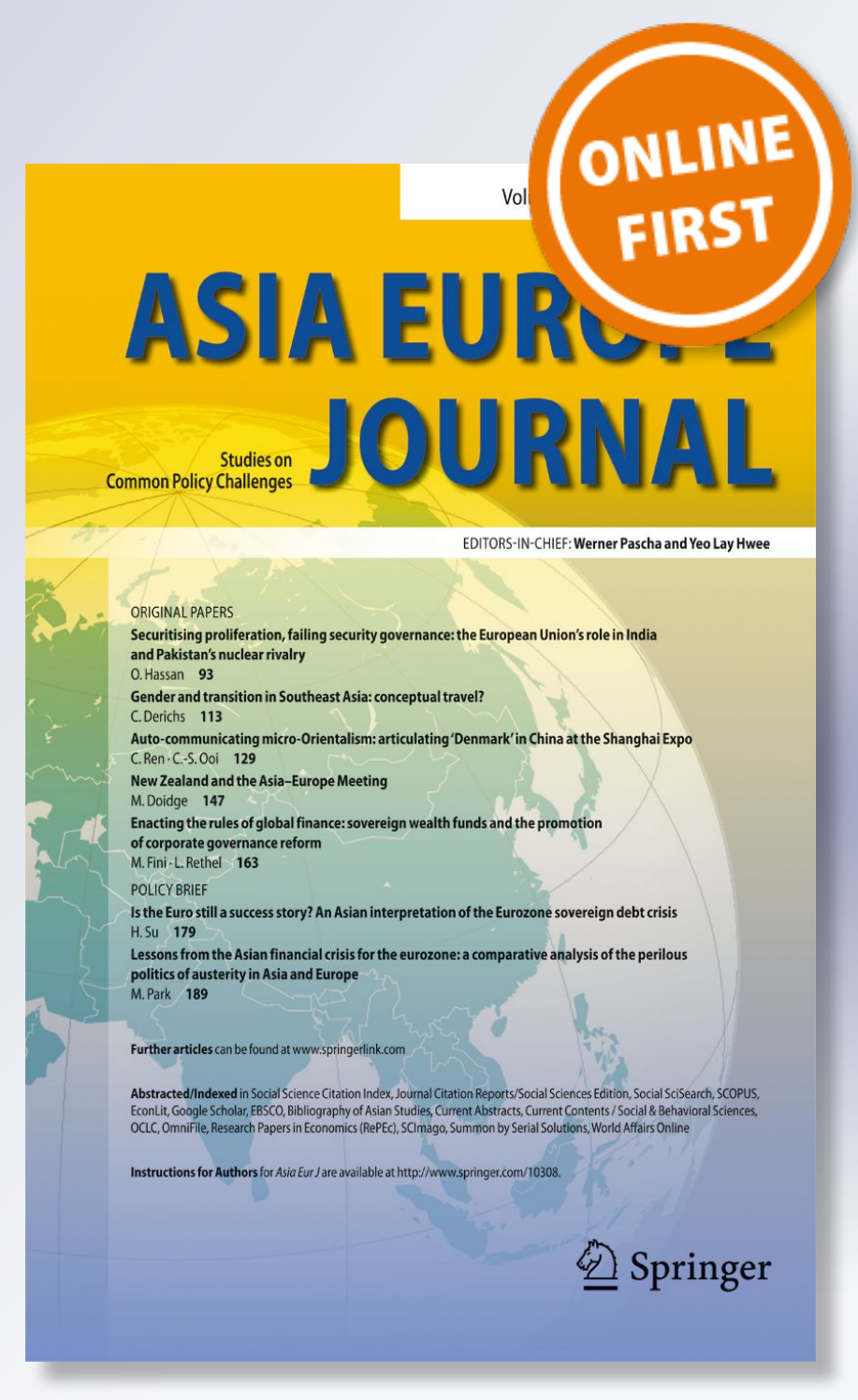

照 Springer 
Your article is protected by copyright and all rights are held exclusively by SpringerVerlag GmbH Germany, part of Springer Nature. This e-offprint is for personal use only and shall not be self-archived in electronic repositories. If you wish to self-archive your article, please use the accepted manuscript version for posting on your own website. You may further deposit the accepted manuscript version in any repository, provided it is only made publicly available 12 months after official publication or later and provided acknowledgement is given to the original source of publication and a link is inserted to the published article on Springer's website. The link must be accompanied by the following text: "The final publication is available at link.springer.com". 


\title{
Trade creation and diversion: effects of EU enlargement on agricultural and food products and selected Asian countries
}

\author{
M. Bruna Zolin ${ }^{1}$ (D) Utai Uprasen ${ }^{2}$
}

Received: 20 December 2017 / Revised: 6 March 2018 / Accepted: 9 March 2018

(C) Springer-Verlag GmbH Germany, part of Springer Nature 2018

\begin{abstract}
Based on estimation of the gravity equation, this article aims to scrutinise the trade effects emanating from the economic integration of the European Union (EU) by focusing on the trade diversion and trade creation effects of the fifth EU enlargement on 12 groups of agricultural and food products. This paper analyses the changes due to the EU's enlargement of trade patterns in the agricultural and food sectors among the EU member states and between EU and non-EU countries as well as the effects of the enlargement on exports of agricultural and food products from selected Asian countries to the EU market. Our analysis shows no decline in exports from EU to non-EU countries. Trade creation effects are significantly high for 4 product groups: seafood, woody plants, beverages and tobacco, and animal and vegetable materials. However, trade diversion effects are found in animal and vegetable oils and textile fibres. Moreover, the economic integration has had no significant effect on exports from Asian countries, namely agricultural and food products. The data of 38 countries cover the period 1999-2015.
\end{abstract}

\section{Introduction}

Seven European Union (EU) enlargements occurred between 1973 and 2013, and currently (i.e. 2018) the EU comprises 28 members. ${ }^{1}$ The 2004 enlargement (the fifth

\footnotetext{
${ }^{1}$ The EU's growth encountered its first major obstacle on June 23, 2016, when the UK voted to leave the EU, the first member state to use a previously untouched release clause.
}

M. Bruna Zolin

zolin@unive.it

Utai Uprasen

utai_uprasen@pknu.ac.kr

1 Department of Economics, Ca' Foscari University of Venice, S. Giobbe 837, Venice, Italy

2 Division of International and Area Studies School of Humanities and Social Sciences, Pukyong National University, Room 901, Education Complex Building (C25) 45 Yongso-Ro, Busan, Nam-Gu 48513, Korea 
enlargement) was the biggest expansion of the EU and incorporated 12 countries, ten of which were from Central or Eastern Europe. ${ }^{2}$ The EU population increased by one-fifth and the agricultural area expanded by $52 \%$. Agriculture represented a heated topic in the negotiation phase, due to its extent and the profound differences in the agricultural sectors of the new and old member states (Bach et al. 2000). To avoid conflicts and control the budget, in 2003, the Common Agricultural Policy was dramatically reformed through considerable reinforcement of the principle introduced in 1992, known as the MacSharry reform and based on the shift from product support to producer support. The enlargement was the impetus for quantitative research that used general and partial models and focused on the pre-accession phase and agricultural production, the EU's budget, welfare and other important issues in agriculture (Tangermann and Josling 1994; Banse 2000; Banse et al. 2000; Swinnen 1996). These studies, however, have not fully captured the impact on international trade in agricultural commodities, especially from Asian countries.

Asia has become the world's most dynamic region for international trade and, therefore, crucial for the EU's economic growth and prosperity. In 2016, according to Eurostat, the extra trade (imports and exports) of the EU's agricultural commodities amounted to $7.6 \%$ of its total international trade. Referring to only the agricultural commodities, the extra-EU flows account for approximately $25 \%$ of total agricultural trade in monetary terms. The largest trading partners for non-EU exports of agricultural products are the United States (US), China and Switzerland followed by Japan, Russia, Norway, Saudi Arabia and Hong Kong - countries that concentrate approximately 50\% of their exports outside the EU. For imports, Brazil and the US rank first with $9 \%$. In the coming years, trade in food and agricultural products is expected to increase due to economic and demographic trends (Abler et al. 2009).

The EU is the mother of all regionalism and, over the years, regional trade agreements (RTAs) ${ }^{3}$ have increased in number and, therefore, the complexity and phenomenon of overlapping memberships have increased. These agreements can have positive or negative effects on global trade.

Starting with these premises, this article, based on estimation of the gravity equation, aims to scrutinise the trade effects emanating from the economic integration of the EU by focusing on the trade diversion and trade creation effects of the fifth EU enlargement on food and agricultural products. Accordingly, our study aims to examine the changes in trade patterns in the agricultural and food sectors among the EU member states and between EU and non-EU ${ }^{4}$ countries as well as the effect of the enlargement on exports of agricultural and food products from selected Asian countries to the EU market. Our selected countries are China, Hong Kong, India, Indonesia, Japan, Korea, Malaysia and Thailand. ${ }^{5}$ We could not include Vietnam because the data series required to feed the model was not available for the analysed period. Notably, however, Vietnam has emerged as one of the world's leading exporters of agro-food commodities and ranks in the top five for aquatic products, rice, coffee, tea, cashews, black pepper, rubber and

\footnotetext{
${ }^{2}$ The enlargement of the EU eastwards could be viewed as a reaction to the fall of the Berlin Wall and disintegration of the states formerly under Soviet influence.

${ }^{3}$ We consider regional trade agreement and free trade agreement to be synonymous.

${ }^{4}$ In non-EU countries, we include our selected Asian countries.

${ }^{5}$ Indonesia, Malaysia and Thailand are members of the Association of Southeast Asian Nations (ASEAN) and the World Trade Organization (WTO).
} 
cassava (World Bank 2016). Our selected Asian countries are a satisfactory representation of trade with the EU in terms of involved population. This research redefines the gravity model of Yang and Martinez-Zarzoso (2014). Data from 38 countries cover the period 1999-2015.

\section{Literature review}

The effects of free-trade areas can be traced back to the concepts of trade creation and trade diversion. According to Viner (1950), trade creation occurs when a cheaper product replaces a more expensive one because of a reduction in trade barriers. Consequently, trade creation increases the volume of trade among the member states. By contrast, the cheaper product of the non-member states is substituted for the more expensive one produced by the member states as a consequence of the elimination of trade barriers. Accordingly, trade diversion creates the misallocation of resources, leading to negative welfare effects, whereas trade creation generates positive effects. Consequently, trade creation and diversion induce changes in trade patterns among the member states and between member and non-member countries. According to Krugman (1991), trading blocs are bad in principle but good in practice. These blocs are also bad because they divide the world into large blocs that refuse to cooperate by exercising market power and erecting trade barriers. Trade diversion is marginal because countries are more likely to trade with their neighbours, partially because transportation costs are contained.

The literature concerning the trade effect emanating from EU's economic integration can be categorised into two groups: ex ante and ex post analyses.

Firstly, we consider ex ante analysis. Herok and Lotze (2000) analysed the impact of the fifth enlargement by focusing on agriculture under the computable general equilibrium model and predicted that imports of food products from the EU15 to CEE (Central Eastern Europe) countries would have increased drastically in 2005, whereas imports of agricultural and food products from third countries into the new member states would have decreased. Similarly, Frandsen et al. (2003) demonstrated that the domestic price supported payments and production that distorted international trade led to adverse effects on the developing countries' export capacity. In addition, Bartošová et al. (2007), using the available data for the period 1996 to 2005, asserted that accession to the EU would increase exports of agricultural products from CEE countries to the EU15 by between 60 and 200\%. By contrast, Drabik et al. (2007) argued that EU enlargement in 2004 would increase Slovakia's agricultural imports from the EU15 and other CEE countries by $31.40 \%$, due to the elimination of tariffs.

Secondly, we consider ex post analysis. The effects of EU enlargement from 1985 to 2000 on agricultural trade creation and diversion for six major agri-food products were analysed by using a gravity model by Sarker and Jayasinghe (2007). Their results suggested that the EU countries traded more among one another than with non-members for the following products: red meat, vegetables, grains, fruits and sugar. In addition, the results also showed that for four of the five commodities mentioned, the EU had reduced its openness to trade with the rest of the world. Notably, the major limitation of their study is that the dependent variable in the equation is total bilateral trade. Using either exports or imports, rather than total bilateral trade, provides more 
reasonable outcomes. Sun and Reed (2010) employed the export of agricultural products as a dependent variable in their research. Using the data available between 1993 and 2007, the findings indicated that significant trade creation existed. The EU15 and EU25 increased intra-trade between member states by 71.6 and $56.8 \%$, respectively. Regarding trade diversion, exports to external, non-member EU15 countries decreased by $6.8 \%$, and imports from the non-EU15 countries decreased by $8.6 \%$. The limitation of their study is that the time span is not long enough to scrutinise trade creation and trade diversion in the EU25. Moreover, Romania and Bulgaria were excluded from their study.

\section{Methodology}

\section{The model}

Some researchers have implemented the spatial equilibrium model (Enke 1951; Samuelson 1952; Takayama and Judge 1971) to illustrate the impact of economic integration on changes in quantity of international trade. For instance, Devadoss et al. (2009) simulated the spatial equilibrium model to quantify the impact of reduction in tariffs on the US and world apple markets. In addition, the effects from trade liberalisation on Canadian dairy products (Abbassi et al. 2008) and Taiwanese fluid milk (Lin 2006) were scrutinised. The spatial equilibrium model is suitable for ex ante studies. Nonetheless, our work focuses on the ex post analysis. Consequently, we adopt a gravity model as our study's framework.

The gravity model is a widely used approach when analysing the trade effects of economic integration. In international economics, the gravity model of trade forecasts bilateral trade flows between two countries based on their economic size and distance and transportation costs. By transposing Newton's law of gravitation to the area of international economics, the first gravity model was developed by Tinbergen in 1962 (Tinbergen 1962) and based on work by Isard (1954). This model is one of the empirically effective methodologies for international trade, performed by regressing the bilateral trade against GDP (gross domestic product). Anderson (1979) was the first to develop a theory and was followed by other economists, such as Bergstrand (1985, 1989) and Deardorff (1998). More recently, a theoretically based log-linear gravity equation was derived. (Anderson and Wincoop 2003) The gravity model of Yang and Martinez-Zarzoso (2014) has been adopted in our study because their model shows changes in trade flows that lead to trade creation and trade diversion effects that can be broken down into changes in trade flows among EU member states, and between the EU and non-EU countries. This concept enables us to observe the changes in export patterns from the EU to EU countries, from the EU to non-EU nations and from non-EU to EU member states.

We have refined their research in two ways. Firstly, we consider the effects of changes in the exchange rate on a country's exports, given that the theory of international trade establishes the relationship between exports and currency values. The depreciation of domestic currency generally boosts exports and vice versa, resulting in currency appreciation. In addition, it has been argued that one of the reasons why a certain country, such as China, has high export values is because of its artificially low 
currency values (Auboin and Ruta 2011). Because China is one of the EU's major trade partners, omitting exchange rates from the model is likely to render a misleading interpretation of the majority of the changes in exports. Secondly, although they have used aggregate trade data, we focus on the sectoral level of agricultural products and food. In addition, the model is augmented by related dummy variables, applied to examine the trade effect on the selected Asian countries.

Data from 38 countries cover the period 1999-2015. Because data at the sectoral level usually contain multiple zero values of trade flows, we overcome this problem by adopting the fixed effects of the Poisson pseudo-maximum likelihood approach (FE-PPML) ${ }^{6}$ as the main estimation method (Santos Silva and Tenreyo 2006), provided there is no consensus on a standard method for solving the problem of zero trade flows (Santos Silva and Tenrero 2009). Our equation is presented as follows. ${ }^{7}$ The equation illustrates that exports are determined by using the standard variables of the gravity equation, such as GDP, population, distance and exchange rate. To capture the effects of EU enlargement on exports and trade creation and trade diversion, the binary dummy variables are included in the equation.

$$
\begin{aligned}
& \ln \left(x_{\text {eit }}\right)=\beta_{0}+\beta_{1} \ln \left(\operatorname{gdp}_{\text {et }}{ }^{*} \mathrm{gdp}_{\mathrm{it}}\right)+\beta_{2} \ln \left(\text { pop }_{\mathrm{et}}{ }^{*} \mathrm{pop}_{\mathrm{it}}\right)+\beta_{3} \operatorname{lndist} \mathrm{ei}_{\mathrm{ei}}+\beta_{4} \ln \operatorname{lxc}_{\mathrm{eit}} \\
& +\beta_{5} d \text { lang }_{\mathrm{ei}}+\beta_{6} \mathrm{~d} \text { border }_{\mathrm{ei}}+\delta_{1} d \text { eu_exp_eu }{ }_{\mathrm{eit}}+\delta_{2} d \text { eu_exp_non }{ }_{\mathrm{eit}} \\
& +\delta_{3} d \text { non_exp_eu } \text { eit }_{1}+\gamma_{1} d \mathrm{cn}_{\mathrm{eit}}+\gamma_{2} d \mathrm{hk}_{\mathrm{eit}}+\gamma_{3} d \text { ind }_{\mathrm{eit}}+\gamma_{4} d \text { ido }_{\text {eit }} \\
& +\gamma_{5} d \mathrm{jp}_{\mathrm{eit}}+\gamma_{6} d \mathrm{kr}_{\mathrm{eit}}+\gamma_{7} d \mathrm{my}_{\mathrm{eit}}+\gamma_{8} d \mathrm{th}_{\mathrm{eit}}+\varepsilon_{\mathrm{eit}}
\end{aligned}
$$

where
$x_{e \text { it }}$
$\operatorname{gdp}_{\mathrm{et}} * \mathrm{gdp}_{\mathrm{it}}$
exports from country $e$ (exporter) to $i$ (importer) in period $t$
popet $_{\text {et }} *$ pop $_{\text {it }}$
product of the countries' GDPs in period $t$
dist $_{\mathrm{ei}}$
product of the countries' populations in period $t$
$\operatorname{exc}_{\text {eit }}$ distance between country $e$ and $i$
$d$ langei $_{\text {en }}$ real exchange rate between countries $e$ and $i$ in period $\mathrm{t}$ dummy variable of language similarity, equal to 1 if country $e$ and country $i$ use the same official language, otherwise 0
$d$ border $_{\mathrm{ei}} \quad$ dummy variable of common border, equal to 1 if country $e$ and country $i$ share common border, otherwise 0
- eu $\mathrm{eit}_{\mathrm{it}}$
non $_{\text {eit }}$
$d$ eu_exp
$\bar{d}$ eu_exp dummy variable of trade effects, equal to 1 if both countries $e$ and $i$ belong to the EU since 2004, otherwise 0 dummy variable of trade effects, equal to 1 if exporter $e$ belongs to the EU and importer $i$ does not since 2004, otherwise 0

\footnotetext{
${ }^{6}$ The reason is that a robust result is still obtained although the heteroscedasticity presents in the estimation. In addition, the fixed effects method is employed to check for the multilateral resistance terms (Anderson and Wincoop 2003).

${ }^{7}$ In addition to the FE-PPML method, the gravity equation was also estimated by using three additional techniques to improve the robustness of the empirical results: the multinomial Poisson maximum likelihood (MPML) technique, panel fixed effect model (FE) and panel random effect model (RE). The MPML technique is adopted based on the suggestion of Head and Mayer (2014). Accordingly, the dependent variable will be the export value for the FE-PPML method, market share of the product for the MPML technique and $\ln (1+$ export) for the FE and RE models, respectively.
} 


\begin{tabular}{|c|c|}
\hline$d$ non_exp & dummy variable of trade effects, equal to 1 if importer $i$ belongs to the \\
\hline- & EU and exporter $e$ does not since 2004 , otherwise 0 \\
\hline $\bar{d} \mathrm{cn}_{\mathrm{eit}}$ & $\begin{array}{l}\text { dummy variable of trade effects, equal to } 1 \text { if exporter } e \text { is China and } \\
\text { importer } i \text { belongs to the EU since } 2004 \text {, otherwise } 0\end{array}$ \\
\hline$d \mathrm{hk}_{\mathrm{eit}}$ & $\begin{array}{l}\text { dummy variable of trade effects, equal to } 1 \text { if exporter } e \text { is Hong Kong } \\
\text { and importer } i \text { belongs to the EU since } 2004 \text {, otherwise } 0\end{array}$ \\
\hline$d$ ind $_{\text {eit }}$ & $\begin{array}{l}\text { dummy variable of trade effects, equal to } 1 \text { if exporter } e \text { is India and } \\
\text { importer } i \text { belongs to the EU since 2004, otherwise } 0\end{array}$ \\
\hline$d$ ido $_{\text {eit }}$ & $\begin{array}{l}\text { dummy variable of trade effects, equal to } 1 \text { if exporter } e \text { is Indonesia } \\
\text { and importer } i \text { belongs to the EU since 2004, otherwise } 0\end{array}$ \\
\hline$d \mathrm{jp}_{\mathrm{eit}}$ & $\begin{array}{l}\text { dummy variable of trade effects, equal to } 1 \text { if exporter } e \text { is Japan and } \\
\text { importer } i \text { belongs to the EU since } 2004 \text {, otherwise } 0\end{array}$ \\
\hline$d \mathrm{kr}_{\mathrm{eit}}$ & $\begin{array}{l}\text { dummy variable of trade effects, equal to } 1 \text { if exporter } e \text { is South Korea } \\
\text { and importer } i \text { belongs to the EU since 2004, otherwise } 0\end{array}$ \\
\hline$d$ my $_{\text {eit }}$ & $\begin{array}{l}\text { dummy variable of trade effects, equal to } 1 \text { if exporter } e \text { is Malaysia } \\
\text { and importer } i \text { belongs to the EU since } 2004 \text {, otherwise } 0\end{array}$ \\
\hline$d$ theit $_{\text {eit }}$ & $\begin{array}{l}\text { dummy variable of trade effects, equal to } 1 \text { if exporter } e \text { is Thailand and } \\
\text { importer } i \text { belongs to the EU since } 2004 \text {, otherwise } 0\end{array}$ \\
\hline$\varepsilon_{\text {eit }}$ & rror term \\
\hline
\end{tabular}

Accordingly, the expected sign of the resulting coefficient estimates can be described as follows. The coefficient of the multiplication of the GDP is expected to be positive. This is because the GDP represents country size, and a big country tends to show high exports and imports simultaneously because of the economies of scale and high capacity of import absorption. The anticipated sign of the coefficient from the multiplicative population term is negative because it implies the self-sufficiency of the respective country pairs. According to Frankel (1997), more natural resources and a large domestic market are available in a country with a sizeable population; therefore, it is less dependent on imports. By contrast, high consumption reduces the quantity of products available for export. Consequently, a country with a large population is less dependent on international trade. Geographical distance remains intrinsic to transport costs. Hence, it is expected to produce a negative coefficient estimate. The exchange rate in our equation is quoted as exporter currency per currency of trade partner. Depreciation of the exporter's currency against the currency of the importer is associated with an increase in the exporter's exports. Therefore, the real exchange rate and exports are presumed to have a positive relationship. As for the coefficients of the binary dummy variables, having the same language and sharing a common border generally facilitates trade between countries. Consequently, they are also presumed to produce positive coefficient estimates.

Regarding the expected plus/minus sign of the trade effects, the literature (Carrère 2006; Magee 2008; Martínez-Zarzoso et al. 2009), including Yang and Martinez-Zarzoso (2014), extended the traditional concepts of trade creation and trade diversion (Viner 1950). According to Yang and Martinez-Zarzoso (2014), trade creation and diversion effects are examined based on export and import perspectives. Nevertheless, for simplicity, we considered trade creation and trade diversion based on exports. The import variables in Yang and Martinez-Zarzoso (2014) are converted into export variables in our framework because exports are actually imports. For instance, if 
country A exports food to country B, it automatically means that country B imports food from country A. To capture trade diversion and trade creation effects based on export perspectives, three dummy variables are added to our gravity equation, namely $d e u_{-}$ $\exp \_u_{e i t}, d e u_{-} \exp n_{n} n_{\text {eit }}$ and $d$ non_exp_eu $u_{\text {eit }}$. The first dummy variable captures trade effects emanating from changes in exports between the EU countries, and the second and third variables capture trade effects emanating from changes in exports from the EU member states to non-EU countries and from non-EU nations to the EU countries, respectively. The positive coefficient of each dummy variable indicates the increase in exports subsequent to economic integration, and the negative one implies the reduction in exports. The expected signs of the coefficients of these three dummy variables $\left(\delta_{1}, \delta_{2}\right.$ and $\delta_{3}$ in our gravity equation) are indeterminate and left to empirical estimations. The summation of these three coefficients yields the net trade effects. Positive net trade effects imply trade creation effects emanating from economic integration. Likewise, the negative values indicate trade diversion effects.

The expected signs of coefficients that indicate the impact of the fifth EU enlargement on exports from eight Asian countries to the EU are uncertain because the reduction of trade barriers between the EU member states may induce the level of intra-bloc trade and reduce the trade volume vis-à-vis the Asian countries. Conversely, EU enlargement expands the export market for Asian nations. Hence, the net effect on Asia depends on these two factors.

\section{Data}

The following are data descriptions. The sample period of the study is from 1999 to 2015. All the data are based on a 12-month period. The panel dataset covers agricultural products, based on the EU definition and the SITC (Standard International Trade Classification) Rev. 3 categories. The analysis involves 12 groups of agricultural products and food (Table 1). For simplicity, the new name of each product group is defined in the last column of Table 1 . The total agricultural products, which are the aggregation of all 12 product groups, are also examined.

The study analyses 38 countries: 20 EU member states, 8 Asian countries, and 10 of the EU's main trade partners. In this study, EU countries with a population of less than 5 million are not considered. The aggregate results follow; however, in a more detailed analysis, trade creation and trade diversion have been linked to each individual country in the EU. The EU countries analysed are Austria, Belgium, Bulgaria, the Czech Republic, Denmark, Finland, France, Germany, Greece, Hungary, Ireland, Italy, the Netherlands, Poland, Portugal, Romania, the Slovak Republic, Spain, Sweden and the UK. The statistics in Appendix Table 6 present the EU's major trade partners in agricultural and food products from 1999 to 2015. Accordingly, these 20 EU countries account for $97.07 \%$ of intra-EU total trade in agricultural and food products. The first three major intra-EU traders are Germany (17.98\%), the Netherlands (13.05\%) and France (12.20\%). The first 8 major Asian countries constitute $16.76 \%$ of extra-EU total trade in agricultural and food products. China $(5.44 \%)$ is the largest trade partner of the EU, followed by Japan (2.66\%) and Indonesia (2.04\%). The rest of selected Asian countries are Hong Kong, India, South Korea, Malaysia and Thailand. The top 10 non-Asian main trade partners of the EU are also included in our study. The US alone holds $11.92 \%$ of the extra-EU total trade in agricultural and food products, followed by 
Table 1 Analysed agricultural and food products

\begin{tabular}{llll}
\hline Group & Description & SITC codes & Products \\
\hline 1 & Live animals, meat and dairy products & $00,01,02$ & Live animals \\
2 & Fish, crustaceans and mollusks & 03 & Seafood \\
3 & Cereal and cereal preparations & 04 & Cereals \\
4 & Vegetables and fruits & 05 & Vegetables and fruits \\
5 & Sugars and preparations and honey & 06 & Sugars \\
6 & Coffee, tea, cocoa and spices & 07 & Colonial products \\
7 & Animal feedstuffs and miscellaneous & 08,09 & Feedstuffs \\
8 & edible products & & Beverages and tobacco \\
9 & Beverages and tobacco & 1 & Textile fibres \\
& Fur skins, natural rubber, fibre, silk, & $21,231,261,263$, & \\
10 & cotton and wool & $264,265,268$ & Animal and vegetable oils \\
11 & Oil seeds and oleaginous fruits and & 22,4 & Woody plants \\
\hline
\end{tabular}

Brazil (7.58\%) and the Russian Federation (5.10\%). The other 7 countries are Argentina, Australia, Canada, Norway, South Africa, Switzerland and Turkey. These 10 countries form $45.91 \%$ of the extra-EU total trade in agricultural and food products.

The data for exports (in USD 1000) were obtained from the UN's Comtrade databases. The statistics concerning GDP (at 2010 constant price, USD) and population size were compiled by the World Bank World Development Indicators. The real exchange rate series were constructed by using the nominal exchange rate data from the Penn World Table. The data of consumer price indices came from the International Monetary Fund's International Financial Statistics. Distance in kilometres is the weighted distance measure, which was obtained from the French Centre d'Etudies and Prospectives et d'Information Internationales (CEPII), and measures the bilateral great-circle distance between the major cities in each country. The dummy variables for language similarity and common borders were also extracted from the CEPII databases.

\section{Empirical results}

\section{Trade creation and trade diversion effects and changes in trade flows}

The trade effects resulting from the fifth EU enlargement can be analysed from three angles, based on the changes in exports following EU enlargement: from the EU to EU countries, from the EU to non-EU nations and from non-EU countries to EU member states. Table 2 elaborates the trade effects, based on our empirical results.

Firstly, the findings based on changes in exports from the EU to the other EU member states reveal that the exports of total agricultural products 
Table 2 Changes in exports, trade creation and trade diversion effects

\begin{tabular}{llllll}
\hline \multirow{2}{*}{ Products } & \multicolumn{2}{l}{ Percentage changes in exports } & \multicolumn{2}{c}{ Net trade effects } \\
& EU/EU & EU/Non-EU & Non-EU/EU & $\%$ & TC or TD \\
\hline Live animals & 0.44 (a) & 0.25 (c) & 0.06 & 0.81 & TC \\
Seafood & 0.72 (a) & 0.39 (b) & 0.57 (a) & 2.76 & TC \\
Cereals & 0.17 (b) & -0.03 & -0.04 & 0.17 & TC \\
Vegetables and fruits & 0.17 (b) & 0.15 & 0.04 & 0.17 & TC \\
Sugars & 0.32 (b) & -0.06 & 0.05 & 0.32 & TC \\
Colonial products & 0.14 & 0.07 & 0.36 (a) & 0.36 & TC \\
Feedstuffs & 0.28 (a) & 0.32 (a) & -0.11 & 0.70 & TC \\
Beverages and tobacco & 0.52 (c) & 0.61 (b) & 0.16 & 1.46 & TC \\
Textile fibres & -0.29 (b) & 0.01 & -0.55 (a) & -0.68 & TD \\
Animal and vegetable oils & 0.12 & -0.17 & -0.28 (b) & -0.28 & TD \\
Woody plants & 0.78 (a) & 0.45 (a) & 0.20 (c) & 2.10 & TC \\
Animal and vegetable materials & 0.59 (a) & 0.43 (a) & 0.07 & 1.28 & TC \\
Total agricultural products & 0.35 (a) & 0.24 (a) & 0.06 & 0.68 & TC \\
\hline
\end{tabular}

$T C$ trade creation effects, $T D$ trade diversion effect

Statistical significance is denoted as (a), (b) and (c) for 1,5 and $10 \%$, respectively

Percentage changes in exports $=\exp$ (trade coefficient) -1 , where the trade coefficient is the value of $\delta_{1}, \delta_{2}$ and $\delta_{3}$ in the gravity equation. For the net trade effects, the trade coefficient equals the summation of $\delta_{1}, \delta_{2}$ and $\delta_{3}$

expanded among the EU nations by $0.35 \%$. The empirical results indicate that the increases in exports of 9 product groups (live animals, seafood, cereals, vegetables and fruits, sugars, feedstuffs, beverages and tobacco, woody plants, animal and vegetable materials) contributed to the expansion of exports of total agricultural products. The exports of textile fibres decreased after the enlargement. Change in exports was not found in colonial products and animal and vegetable oils.

Secondly, when the changes in exports from EU member states to non-EU countries were investigated, the findings revealed that the exports of total agricultural products also increased by $0.24 \%$. The increase in such exports is explained by the increase in exports of 6 product groups: live animals, seafood, feedstuffs, beverages and tobacco, woody plants, and animal and vegetable materials. There was no change in the exports of the other 6 product groups.

Thirdly, the effects of EU enlargement on exports from non-EU countries to EU member states - or the imports of EU nations from non-EU countries in the view point of Yang and Martinez-Zarzoso (2014) - indicate there was no change in exports of total agricultural products. Nonetheless, the EU's fifth enlargement boosted exports of certain products from non-EU nations to EU member countries but only in 3 product groups: seafood, colonial products and woody plants. Furthermore, the decreases in exports from non-EU countries to EU nations were identified in 2 product groups: textile fibres and animal and vegetable oils. 
The net trade effects resulting from the EU's fifth integration can be obtained by combining these three effects. The empirical evidence affirms that trade creation effects exist when total agricultural products are considered. The EU's enlargement increased the exports of total agricultural products by $0.68 \%$. In addition, the trade creation effects were also present in 10 of the product groups studied. Among them, the trade creation effects were significantly higher (greater than 1.00 percentage change) than in 4 other product groups, namely seafood, woody plants, beverages and tobacco, and animal and vegetable materials. Exports of these 4 product groups increased by 2.76 , $2.10,1.46$ and $1.28 \%$, respectively. Trade diversion effects were found in animal and vegetable oils and textile fibres. Although net exports for the former decreased by $0.28 \%$, the latter decreased by $-0.68 \% .^{8}$

\section{The impact on exports of the selected Asian countries}

The trade effects emanating from the EU's fifth enlargement on selected Asian countries are scrutinised in this study. We investigate the impact of EU expansion on exports from the Asian countries to the EU market. The impact on imports into Asian nations from EU countries are not our focal point because the third group of countries tends to concern potentially negative effects, which may lower their exports to EU countries. The reason for this phenomenon is that EU integration increases the level of intra-EU trade; therefore, the reduction in extra-EU trade is plausible.

The effects of the enlargement on exports can be examined through the coefficients of the dummy variables of 8 Asian countries $\left(\gamma_{1}\right.$ to $\gamma_{8}$ in the gravity equation). The percentage change in exports is calculated and presented in Table 3.

The empirical results indicate that only 3 out of 8 countries incur a significant impact on the exports of total agricultural products to the EU market. Hong Kong and South Korea's exports of total agricultural products decreased by -0.49 and $-0.30 \%$, respectively. Conversely, the total exports of agricultural products from Indonesia to the EU increased by $0.26 \%$ after EU enlargement. There was no significant change in exports of total agricultural products from China, India, Japan, Malaysia and Thailand. However, the analysis at a product group level reveals that EU integration generated changes in exports of certain products in various countries, as follows.

China: The enlargement decreased the exports of animal and vegetable oils by $-0.56 \%$ and increased the exports of feedstuffs by $0.43 \%$. In addition, the exports of woody plants increased by $1.39 \%$. Because the 3 product groups affected accounted for only $12.54 \%$ of total exports of agricultural products to the EU market, the impact of enlargement on aggregate agricultural exports is not significant.

\footnotetext{
${ }^{8}$ Notably, the findings on trade creation and trade diversion effects from the FE-PPML method are in line with the empirical results from the MPML, FE and RE techniques, in general. For instance, based on Table 2, the FE-PPML method indicates the existence of trade diversion in textile fibres $(-0.68 \%$ in net trade effects), but the trade diversion in the same industry is also revealed in the other three techniques, although each method produces slightly different values of net trade effects $(-11,-49$ and $-49 \%$ for the MPML, FE and RE models, respectively). The consistency in trade creation and trade diversion from the estimation of the four techniques is also displayed in the other industries. See Appendix-1 for the related details.
} 
Trade creation and diversion: effects of EU enlargement on...

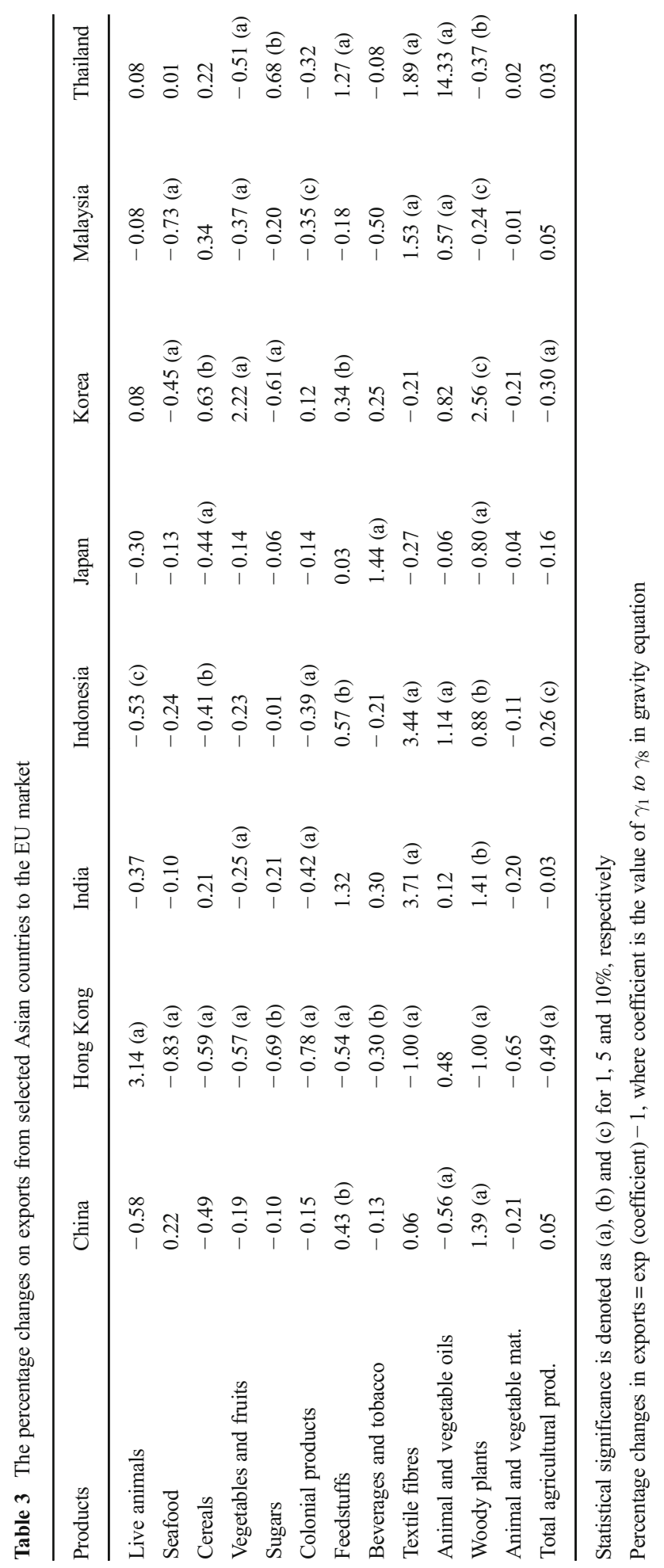


Hong Kong ${ }^{9}$ : Most exports from Hong Kong to the EU decreased. The findings reveal that exports from 9 product groups decreased after the fifth EU integration, namely seafood, cereals, vegetables and fruits, sugars, colonial products, feedstuffs, beverages and tobacco, textile fibres and woody plants. These 9 product groups constitute $92 \%$ of total exports of agricultural products to the EU. Feedstuffs, which accounts for $73.53 \%$ of agricultural products, decreased by $-0.54 \%$.

India: In contrast with Hong Kong, EU enlargement did not affect the majority of exports of agricultural products from India to the EU market. Empirical findings show that no significant impact was detected in 8 of the studied groups (live animals, seafood, cereals, sugars, feedstuffs, beverages and tobacco, animal and vegetable oils, and animal and vegetable materials), which represented $62.22 \%$ of total agricultural exports from India to the EU. The exports of 2 important product groups, vegetables and fruits and colonial products, decreased by -0.25 and $-0.42 \%$, respectively. By contrast, 2 product groups saw exports increase: textile fibres and woody plants. However, neither represents India's key exports to EU countries.

Indonesia: The exports of 3 product groups (live animals, cereals and colonial products) decreased, whereas 4 product groups (feedstuffs, textile fibres, animal and vegetable oils, woody plants) increased the exports from Indonesia to the EU market. Animal and vegetable oils, the largest exporting product group (representing $52.33 \%$ of total exports in agricultural products), increased by $1.14 \%$ after EU integration.

Japan: The empirical results reveal that the exports of 3 product groups, which constitute $14.63 \%$ of agricultural exports, were affected by EU integration. Exports of beverages and tobacco increased by $1.44 \%$, and exports of cereals and woody plants shrank by -0.44 and $-0.80 \%$, respectively.

Korea: The decrease in exports of total agricultural products from South Korea to the EU following the fifth enlargement was mainly due to decreases in seafood exports $(-0.45 \%)$, that account $52.89 \%$ of total exports in agricultural products. A decrease in exports is also observed in sugars, and there is an increase in exports of cereals, vegetables and fruits, feedstuffs and woody plants. The export share of these 4product groups is only $23.12 \%$ of total agricultural exports.

Malaysia: The findings indicate that exports of 2 product groups (animal and vegetable oils and textile fibres) increased, whereas the exports of vegetables and fruit decreased. Exports of animal and vegetable oils, representing the majority share $(56.76 \%)$ of agricultural exports, expanded by $0.57 \%$. There were also reductions in exports in the other 3 product groups: seafood, colonial products and woody plants $(-0.73,-0.35$ and $0.24 \%$, respectively).

\footnotetext{
${ }^{9}$ Hong Kong is not a big producer of agricultural commodities but a great re-exporter of these products. For simplicity, in our work, live animals include meat and dairy products. The percentage in Table 3 could refer to meat and dairy products that are generally not perishable (ChinaAg Consulting (2018))
} 
Thailand $^{10}$ : The exports of 6 product groups, representing $57.03 \%$ of total agricultural exports to the EU, were not affected by the EU enlargement. However, exports of vegetables and fruits and woody plants declined by 0.51 and $-0.37 \%$, respectively. Exports of the other 4 product groups increased after the EU enlargement, namely sugars, feedstuffs, textile fibres, and animal and vegetable oils.

In summary, although the EU enlargement generates positive and negative impacts on exports of certain industries from certain countries, the empirical findings reveal that the most affected industry of each Asian country shows a positive effect in its export. Although textile fibres are the most affected products in India (3.71\%), Indonesia (3.44\%) and Malaysia (1.53\%), it is woody plants in the case of China (1.39\%) and South Korea $(2.56 \%)$. For Hong Kong, Japan and Thailand, they are live animals (3.14\%), beverages, tobacco (1.44\%), and animal and vegetable oils (14.33\%), respectively.

Considering the percentage changes in exports from selected Asian countries to the EU market (Table 3), it is worth investigating the import penetration rate of the EU countries simultaneously. The import penetration ratio represents the degree of domestic demand, satisfied by the imports of certain industries. Nonetheless, the incomplete data sets of production output at industry level do not allow us to calculate for the import penetration rate. Consequently, we calculate the export share of individual products from the selected Asian countries to the EU market with respect to the world, as in Appendix Table 5. The numbers exhibit the export share of significantly affected products, before and after the EU enlargement. Generally, the values of export share in Appendix Table 5 are in line with our empirical findings in Table 3. For example, although the percentage changes on the exports of feedstuffs from China to the EU market (Table 3) are $0.43 \%$, the export share (in Appendix Table 5) of the same product increases from 6.86 to $10.25 \%$, after the enlargement.

\section{Standard variables of gravity equation}

The empirical results reveal that most of the fundamental variables produce the sign predicted by the gravity model. The product of GDP between exporters and importers has a positive effect on the exports of total agricultural products and all 12 of the studied product groups. A $1 \%$ increase in the multiplication of GDP increases exports of total agricultural products by $1.06 \% .{ }^{11}$ The coefficients from 12 product groups lie between 0.70 and $1.43 \%$. The coefficient estimate of the population variable is -0.95 for total agricultural exports and are negatively significant in 7 product groups.

Turning to the impacts of the real exchange rate, only 2 of the product groups show a significant effect on exports bearing the expected signs.

\footnotetext{
${ }^{10}$ Thailand is one of the main producer countries at the world level of soybean and rapeseed. The country, even if in a small scale, is becoming an important player in this market (Rosillo-Calle et al. 2009; Indexmundi 2018)

${ }^{11}$ The results from the MPML, FE and RE models are in line with the FE-PPML method. See Appendix 1.
} 
Generally, a $1 \%$ increase in the real exchange rate promotes the exports of aggregated agricultural products by $0.09 \%$. The estimated coefficients from our model indicate that trade costs, proxied by distance, are completely in line with the prediction of the model. All 12 product groups together with the total agricultural exports show the significant negative signs. Findings assert that increases in trade costs reduce exports, in general. The coefficients of dummy variables of language similarity and common borders also produce the sign expected. Although the exports of 10 product groups produce significant positive coefficients for language similarity, all 12 product groups show the significant positive effects from the common border variable. The same effect is also found in total agricultural exports. See Appendix Table 4 for all coefficient estimates of every studied variable from the four estimation techniques.

\section{Conclusion}

The literature that does not favour regional free trade agreements argues that these agreements create the distortion of trade because they favour inefficient countries (in terms of productivity) to the detriment of non-members. The purpose of our work was to explore the impact of the fifth EU enlargement in terms of trade creation and trade diversion by focusing on agricultural and food products among the EU member states and between EU and non-EU countries and, in particular, the effect of the enlargement on exports of the selected Asian countries.

Our research findings are presented as three major points.

First: Changes in exports. The empirical results indicate that EU enlargement increases exports between EU countries in 9 product groups (live animals, seafood, cereals, vegetables and fruits, sugars, feedstuffs, beverages and tobacco, woody plants, animal and vegetable materials) and increases exports from EU members to non-EU nations in 6 product groups (live animals, seafood, feedstuffs, beverages and tobacco, woody plants, and animal and vegetable materials); however, it increases exports from non-EU countries to EU member states in 3 product groups (seafood, colonial products and woody plants). Although the exports of textile fibres decrease between EU countries, reductions in exports of textile fibres and animal and vegetable oils are detected in exports from non-EU countries to the EU member states. No decrease in exports from the EU to non-EU countries is observed.

Second: Trade creation and trade diversion effects. Changes in the aforementioned exports create trade creation effects in 10 product groups (live animals, seafood, cereals, vegetables and fruits, sugars, colonial products, feedstuffs, beverages and tobacco, woody plants, and animal and vegetable materials) including the total agricultural products. Trade creation effects are significantly high in 4 product groups (seafood, woody plants, beverages and tobacco, and animal and vegetable 
materials). However, trade diversion effects are found in animal and vegetable oils and textile fibres.

Third: Effects on the exports of the selected Asian countries with regard to total agricultural products exports. Significant effects of the EU enlargement on the exports of total agricultural products exports from Asian countries to the EU market are found in 3 out of 8 countries. Hong Kong and South Korea experienced a decrease in exports, whereas Indonesia's exports of total agricultural products increased. Product group analysis reveals that China was unaffected, with the exception of higher exports of woody plants. The EU's fifth enlargement did not significantly impact in India and Japan, with 8 out of 12 groups unaffected. The decrease in Hong Kong's exports is present in 9 product groups, whereas South Korea's decline was mostly caused by decreases in seafood exports. By contrast, the increases in exports of animal and vegetable oils, which constitute $52.33 \%$ of the country's total agricultural product exports, were the major contributing factors of increased total agricultural exports from Indonesia to the EU. Malaysia is in a similar position. Exports of animal and vegetable oils, which represent its largest share of $(56.76 \%)$ of total agricultural exports to the EU, increased significantly after the enlargement. Although there was no major impact of the enlargement on Thailand's total agricultural exports, the country was still affected by the reduction of exports of vegetables and fruit.

To sum up, this analysis shows that the process of European economic integration has expanded trade among member states but has had no significant effect on trade with Asian countries regarding agricultural and food products. We can conclude that, as Krugman states (1991), regional agreements are not bad, and the effects of trade creation are greater than those of trade diversion.

The same results were achieved by Kahouli and Maktouf (2015), whodespite including the impact of the financial crisis on exports and not disaggregating among the various components - concluded by arguing that FTAs increase the export flows among member countries because they remove the barriers to trade for goods, services, and capital. Urata and Okabe (2014), using a panel of 20 products for 67 countries and areas, observed marginal effects of trade creation and trade diversion deriving from the formation of RTAs. In their work, in the case of FTAs, trade creation was found in only one product (cereals and cereal preparation), which was included among the agricultural products capable of generating trade creation in our work. They also assert that in the case of agricultural products, this effect is particularly strong. Trade diversion in developed countries who are members of a free trade agreement has been found only in the case of medical and pharmaceutical products. In this regard, the work of Dai et al. (2014) finally defines an exception and an anomaly: the positive effect for outside FTAs in the food sector. The limitation of our research is that we fail to consider the impacts on other nations of the agreements signed by the EU and non-EU countries or by the selected Asian countries in the period under review. However, our aim was to analyse the 
impact of the fifth EU enlargement among the EU member states and between EU and non-EU countries and, in particular, the effect of the enlargement on the exports of the selected Asian countries, rather than conduct a comparison of its effects on the different trade agreements.

\section{Appendix 1}

Table 4 Coefficient estimates of all studied industries

\begin{tabular}{|c|c|c|c|c|c|c|c|c|}
\hline \multirow[b]{2}{*}{ Variable } & \multicolumn{4}{|c|}{ Live animals } & \multicolumn{4}{|c|}{ Seafood } \\
\hline & FE-PPML & MPML & FE & RE & FE-PPML & MPML & FE & RE \\
\hline gdp & $1.343 \mathrm{a}$ & $0.248 \mathrm{a}$ & $0.303 \mathrm{a}$ & $0.300 \mathrm{a}$ & $1.007 \mathrm{a}$ & $0.297 \mathrm{a}$ & $0.396 \mathrm{a}$ & $0.395 \mathrm{a}$ \\
\hline pop & $-1.286 \mathrm{a}$ & $-1.020 \mathrm{a}$ & $-0.587 \mathrm{~b}$ & $-0.585 b$ & -0.291 & $-1.038 \mathrm{a}$ & $-0.419 b$ & $-0.423 b$ \\
\hline dist & & $-1.018 \mathrm{a}$ & & $-0.752 \mathrm{a}$ & & $-1.029 \mathrm{a}$ & & $-0.839 a$ \\
\hline exc & $0.332 \mathrm{a}$ & -0.091 & $0.078 \mathrm{a}$ & $0.079 \mathrm{~b}$ & 0.143 & -0.021 & $0.102 \mathrm{a}$ & $0.102 \mathrm{a}$ \\
\hline lang & & $0.187 \mathrm{a}$ & & $0.323 \mathrm{a}$ & & $0.354 \mathrm{a}$ & & 0.165 \\
\hline border & & $1.058 \mathrm{a}$ & & $1.193 \mathrm{a}$ & & $0.821 \mathrm{a}$ & & $0.630 \mathrm{a}$ \\
\hline eu_eu & $0.368 \mathrm{a}$ & $0.098 \mathrm{~b}$ & $0.663 \mathrm{a}$ & $0.661 \mathrm{a}$ & $0.545 \mathrm{a}$ & 0.042 & $0.145 \mathrm{a}$ & $0.145 \mathrm{a}$ \\
\hline eu_non & $0.225 \mathrm{c}$ & $-0.518 \mathrm{a}$ & $0.134 \mathrm{~b}$ & $0.120 \mathrm{~b}$ & $0.328 \mathrm{~b}$ & $-0.594 a$ & $-0.199 \mathrm{a}$ & $-0.199 a$ \\
\hline non_eu & 0.062 & $-0.557 \mathrm{a}$ & $-0.285 \mathrm{a}$ & $-0.314 a$ & $0.452 \mathrm{a}$ & $-0.164 b$ & $-0.111 b$ & $-0.111 b$ \\
\hline cn & -0.867 & $-0.926 a$ & -0.146 & -0.135 & 0.196 & $0.350 \mathrm{a}$ & $0.702 \mathrm{a}$ & $0.693 \mathrm{a}$ \\
\hline hk & $1.418 \mathrm{a}$ & $-2.629 a$ & $-0.170 \mathrm{a}$ & $-0.116 a$ & $-1.749 a$ & -0.153 & $-0.389 a$ & $-0.366 \mathrm{a}$ \\
\hline ind & -0.465 & $-0.957 \mathrm{a}$ & -0.129 & -0.107 & -0.100 & $0.344 \mathrm{a}$ & 0.173 & 0.174 \\
\hline ido & $-0.758 \mathrm{c}$ & $1.448 \mathrm{a}$ & $-0.179 b$ & $-0.133 \mathrm{c}$ & -0.283 & $-0.428 \mathrm{a}$ & 0.005 & 0.008 \\
\hline jp & -0.362 & $-0.790 \mathrm{a}$ & $-0.111 b$ & -0.082 & -0.138 & $-2.261 \mathrm{a}$ & -0.104 & -0.123 \\
\hline $\mathbf{k r}$ & 0.077 & $-1.491 \mathrm{a}$ & $-0.140 \mathrm{a}$ & $-0.117 \mathrm{a}$ & $-0.585 \mathrm{a}$ & -0.140 & $-0.330 \mathrm{a}$ & $-0.328 \mathrm{a}$ \\
\hline my & -0.079 & $-1.278 \mathrm{a}$ & $-0.104 b$ & -0.064 & $-1.296 \mathrm{a}$ & -0.049 & $-0.702 \mathrm{a}$ & $-0.686 a$ \\
\hline th & 0.078 & $1.661 \mathrm{a}$ & 0.250 & $0.285 \mathrm{c}$ & 0.012 & -0.209 & $0.242 \mathrm{a}$ & $0.238 \mathrm{a}$ \\
\hline const & & $19.515 \mathrm{a}$ & 3.778 & 9.591 & & $18.075 \mathrm{~b}$ & -5.578 & -0.705 \\
\hline No. Obs. & 23528 & 23902 & 23902 & 23902 & 22899 & 23902 & 23902 & 23902 \\
\hline$R^{2}$ & & 0.644 & 0.062 & 0.751 & & 0.538 & 0.064 & 0.706 \\
\hline Log pseudo. & -115585 & -1540 & & & -74042 & -1842 & & \\
\hline Hausman & & & 96.160 & & & & 43.460 & \\
\hline \multirow[b]{2}{*}{ Variable } & \multicolumn{4}{|c|}{ Cereals } & \multicolumn{4}{|c|}{ Vegetables and fruits } \\
\hline & FE-PPML & MPML & FE & RE & FE-PPML & MPML & FE & RE \\
\hline gdp & $0.725 \mathrm{~b}$ & $0.194 \mathrm{a}$ & $0.357 \mathrm{a}$ & $0.356 \mathrm{a}$ & $0.925 \mathrm{a}$ & $0.245 \mathrm{a}$ & $0.610 \mathrm{a}$ & $0.610 \mathrm{a}$ \\
\hline pop & -0.607 & $-0.424 \mathrm{c}$ & $-0.945 \mathrm{a}$ & $-0.944 a$ & -0.120 & $-0.845 a$ & -0.166 & -0.166 \\
\hline dist & & $-1.213 \mathrm{a}$ & & $-0.975 \mathrm{a}$ & & $-1.228 \mathrm{a}$ & & $-0.911 \mathrm{a}$ \\
\hline exc & 0.031 & 0.050 & $0.194 \mathrm{a}$ & $0.194 \mathrm{a}$ & 0.064 & -0.032 & $0.167 \mathrm{a}$ & $0.167 \mathrm{a}$ \\
\hline lang & & $0.247 \mathrm{a}$ & & $0.257 \mathrm{a}$ & & $0.560 \mathrm{a}$ & & $0.296 \mathrm{~b}$ \\
\hline border & & $1.044 \mathrm{a}$ & & $1.093 \mathrm{a}$ & & $0.702 \mathrm{a}$ & & $0.679 \mathrm{a}$ \\
\hline eu_eu & $0.159 \mathrm{~b}$ & $0.099 \mathrm{a}$ & $0.325 \mathrm{a}$ & $0.325 \mathrm{a}$ & $0.153 \mathrm{~b}$ & -0.036 & $0.245 \mathrm{a}$ & $0.245 \mathrm{a}$ \\
\hline eu_non & -0.029 & $-0.407 \mathrm{a}$ & $-0.152 \mathrm{a}$ & $-0.150 a$ & 0.138 & -0.053 & $-0.078 \mathrm{c}$ & $-0.083 \mathrm{c}$ \\
\hline non_eu & -0.038 & $-0.163 \mathrm{~b}$ & $-0.280 a$ & $-0.291 \mathrm{a}$ & 0.043 & -0.040 & $-0.092 b$ & $-0.101 \mathrm{~b}$ \\
\hline cn & -0.667 & $-0.953 \mathrm{a}$ & $-0.326 b$ & $-0.323 b$ & -0.207 & $-0.270 \mathrm{~b}$ & $0.302 \mathrm{a}$ & $0.292 \mathrm{a}$ \\
\hline hk & $-0.900 \mathrm{a}$ & -0.227 & $-0.383 a$ & $-0.305 \mathrm{a}$ & $-0.838 \mathrm{a}$ & 0.284 & $-0.536 \mathrm{a}$ & $-0.506 \mathrm{a}$ \\
\hline ind & 0.194 & 0.138 & 0.118 & 0.138 & $-0.289 a$ & -0.079 & -0.010 & -0.002 \\
\hline ido & $-0.524 b$ & $-1.119 a$ & $-0.343 \mathrm{a}$ & $-0.302 \mathrm{a}$ & -0.265 & $-0.214 \mathrm{c}$ & $-0.182 \mathrm{c}$ & $-0.173 \mathrm{c}$ \\
\hline jp & $-0.584 \mathrm{a}$ & $-1.046 \mathrm{a}$ & $-0.257 \mathrm{a}$ & $-0.225 \mathrm{a}$ & -0.153 & $-1.887 \mathrm{a}$ & $-0.282 a$ & $-0.272 a$ \\
\hline $\mathbf{k r}$ & $0.489 \mathrm{~b}$ & $-1.165 \mathrm{a}$ & $-0.198 \mathrm{a}$ & $-0.180 a$ & $1.173 \mathrm{a}$ & $-1.842 \mathrm{a}$ & $-0.313 \mathrm{a}$ & $-0.309 a$ \\
\hline my & 0.293 & $-0.623 a$ & $-0.174 b$ & $-0.140 \mathrm{c}$ & $-0.464 \mathrm{a}$ & $-0.443 \mathrm{a}$ & $-0.483 \mathrm{a}$ & $-0.468 \mathrm{a}$ \\
\hline th & 0.197 & 0.003 & $0.266 \mathrm{~b}$ & $0.257 \mathrm{~b}$ & $-0.715 \mathrm{a}$ & $-0.505 \mathrm{a}$ & $-0.242 b$ & $-0.234 \mathrm{~b}$ \\
\hline const & & 3.269 & 11.063 & $18.993 \mathrm{~b}$ & & $14.350 \mathrm{~b}$ & $-22.296 a$ & $-19.258 \mathrm{a}$ \\
\hline
\end{tabular}


Trade creation and diversion: effects of EU enlargement on...

\begin{tabular}{|c|c|c|c|c|c|c|c|c|}
\hline No. Obs. & 23596 & 23902 & 23902 & 23902 & 22848 & 23273 & 23902 & 23902 \\
\hline$R^{2}$ & & 0.695 & 0.003 & 0.704 & & 0.631 & 0.186 & 0.774 \\
\hline Log pseudo. & -117757 & -1473 & & & -74437 & -1712 & & \\
\hline Hausman & & & 64.910 & & & & 62.610 & \\
\hline & \multicolumn{4}{|c|}{ Sugars } & \multicolumn{4}{|c|}{ Colonial products } \\
\hline Variable & FE-PPML & MPML & FE & $\mathbf{R E}$ & FE-PPML & MPML & FE & RE \\
\hline gdp & $1.242 \mathrm{a}$ & $0.150 \mathrm{~b}$ & $0.396 \mathrm{a}$ & $0.396 \mathrm{a}$ & $0.699 \mathrm{a}$ & $0.157 \mathrm{~b}$ & $0.365 \mathrm{a}$ & $0.365 \mathrm{a}$ \\
\hline pop & -1.094 & $-0.939 a$ & $-0.914 \mathrm{a}$ & $-0.916 \mathrm{a}$ & $-1.307 \mathrm{a}$ & $-1.156 \mathrm{a}$ & $-0.477 \mathrm{~b}$ & $-0.473 b$ \\
\hline dist & & $-1.435 \mathrm{a}$ & & $-0.717 \mathrm{a}$ & & $-1.250 \mathrm{a}$ & & $-0.698 \mathrm{a}$ \\
\hline exc & 0.092 & $0.115 \mathrm{c}$ & -0.020 & -0.021 & $-0.177 b$ & -0.047 & -0.044 & -0.044 \\
\hline lang & & $0.140 \mathrm{a}$ & & $0.206 \mathrm{a}$ & & $0.292 \mathrm{a}$ & & $0.314 \mathrm{a}$ \\
\hline border & & $0.754 \mathrm{a}$ & & $0.964 \mathrm{a}$ & & $0.908 \mathrm{a}$ & & $1.019 \mathrm{a}$ \\
\hline eu_eu & $0.275 \mathrm{~b}$ & $0.206 \mathrm{a}$ & $0.305 \mathrm{a}$ & $0.305 \mathrm{a}$ & 0.127 & 0.057 & $0.297 \mathrm{a}$ & $0.298 \mathrm{a}$ \\
\hline eu_non & -0.061 & $-0.329 a$ & $-0.150 \mathrm{a}$ & $-0.149 \mathrm{a}$ & 0.066 & 0.051 & -0.067 & -0.059 \\
\hline non_eu & 0.046 & -0.106 & $-0.088 \mathrm{c}$ & $-0.093 \mathrm{~b}$ & $0.308 \mathrm{a}$ & -0.046 & $-0.187 \mathrm{a}$ & $-0.183 a$ \\
\hline cn & -0.109 & $0.815 \mathrm{a}$ & $0.276 \mathrm{a}$ & $0.263 \mathrm{~b}$ & -0.162 & $0.489 \mathrm{a}$ & 0.134 & 0.124 \\
\hline hk & $-1.185 b$ & $-0.903 \mathrm{a}$ & $-0.318 \mathrm{a}$ & $-0.257 \mathrm{a}$ & $-1.527 \mathrm{a}$ & -0.006 & $-0.348 \mathrm{a}$ & $-0.301 \mathrm{a}$ \\
\hline ind & -0.237 & 0.191 & -0.113 & -0.084 & $-0.540 \mathrm{a}$ & $0.496 \mathrm{a}$ & 0.068 & 0.080 \\
\hline ido & -0.006 & 0.116 & $-0.183 b$ & $-0.159 b$ & $-0.501 \mathrm{a}$ & $0.410 \mathrm{a}$ & -0.041 & -0.041 \\
\hline jp & -0.057 & $-0.763 a$ & $-0.205 \mathrm{a}$ & $-0.184 a$ & -0.151 & $-0.618 \mathrm{a}$ & $-0.120 \mathrm{c}$ & $-0.116 c$ \\
\hline $\mathbf{k r}$ & $-0.949 a$ & $-1.788 \mathrm{a}$ & $-0.340 \mathrm{a}$ & $-0.330 \mathrm{a}$ & 0.109 & $-1.232 \mathrm{a}$ & $-0.263 \mathrm{a}$ & $-0.263 \mathrm{a}$ \\
\hline my & -0.217 & $-1.447 \mathrm{a}$ & $-0.221 \mathrm{a}$ & $-0.196 a$ & $-0.427 \mathrm{c}$ & 0.202 & -0.125 & -0.135 \\
\hline th & $0.519 \mathrm{~b}$ & $-0.713 a$ & 0.151 & 0.118 & -0.382 & $0.453 \mathrm{~b}$ & $-0.225 \mathrm{c}$ & -0.203 \\
\hline const & & $23.240 \mathrm{a}$ & 7.563 & $13.330 \mathrm{c}$ & & $29.290 \mathrm{a}$ & -2.453 & 1.068 \\
\hline No. Obs. & 23392 & 23902 & 23902 & 23902 & 23426 & 23902 & 23902 & 23902 \\
\hline$R^{2}$ & & 0.677 & 0.001 & 0.677 & & 0.736 & 0.027 & 0.774 \\
\hline Log pseudo. & -52457 & -1520 & & & -51196 & -1601 & & \\
\hline Hausman & & & 85.240 & & & & 65.470 & \\
\hline & \multicolumn{4}{|c|}{ Feedstuffs } & \multicolumn{4}{|c|}{ Beverages and tobacco } \\
\hline Variable & FE-PPML & MPML & FE & RE & FE-PPML & MPML & FE & $\mathbf{R E}$ \\
\hline gdp & $1.118 \mathrm{a}$ & $0.171 \mathrm{a}$ & $0.566 \mathrm{a}$ & $0.568 \mathrm{a}$ & $1.332 \mathrm{a}$ & $0.142 \mathrm{c}$ & $0.562 \mathrm{a}$ & $0.560 \mathrm{a}$ \\
\hline pop & $-0.890 \mathrm{~b}$ & $-0.435 b$ & $-0.700 \mathrm{a}$ & $-0.703 a$ & $-1.456 b$ & $-0.685 b$ & $-0.906 \mathrm{a}$ & $-0.910 a$ \\
\hline dist & & $-0.988 \mathrm{a}$ & & $-0.952 \mathrm{a}$ & & $-0.938 \mathrm{a}$ & & $-0.720 a$ \\
\hline exc & 0.059 & 0.008 & $0.071 \mathrm{c}$ & $0.071 \mathrm{c}$ & 0.110 & 0.066 & $0.069 \mathrm{c}$ & $0.069 \mathrm{c}$ \\
\hline lang & & $0.349 \mathrm{a}$ & & $0.336 \mathrm{a}$ & & $0.289 \mathrm{a}$ & & $0.424 \mathrm{a}$ \\
\hline border & & $0.981 \mathrm{a}$ & & $0.874 \mathrm{a}$ & & $0.654 \mathrm{a}$ & & $0.740 \mathrm{a}$ \\
\hline eu_eu & $0.248 \mathrm{a}$ & -0.013 & $0.263 \mathrm{a}$ & $0.264 \mathrm{a}$ & $0.421 \mathrm{c}$ & -0.052 & $0.319 \mathrm{a}$ & $0.319 \mathrm{a}$ \\
\hline eu_non & $0.280 \mathrm{a}$ & $-0.088 \mathrm{c}$ & $-0.097 \mathrm{c}$ & $-0.090 \mathrm{c}$ & $0.478 \mathrm{~b}$ & 0.110 & 0.069 & 0.073 \\
\hline non_eu & -0.120 & -0.030 & $-0.212 \mathrm{a}$ & $-0.202 \mathrm{a}$ & 0.149 & -0.018 & -0.058 & -0.056 \\
\hline cn & $0.361 \mathrm{~b}$ & $-0.558 \mathrm{a}$ & $0.229 \mathrm{c}$ & $0.202 \mathrm{c}$ & -0.142 & $-0.462 \mathrm{a}$ & -0.164 & -0.170 \\
\hline hk & $-0.765 \mathrm{a}$ & $0.317 \mathrm{c}$ & $-0.553 \mathrm{a}$ & $-0.513 a$ & $-0.360 b$ & $-2.611 a$ & $-0.487 \mathrm{a}$ & $-0.472 \mathrm{a}$ \\
\hline ind & 0.842 & $-1.421 \mathrm{a}$ & -0.036 & -0.053 & 0.256 & $0.790 \mathrm{a}$ & -0.041 & -0.017 \\
\hline ido & $0.453 \mathrm{~b}$ & 0.066 & -0.102 & -0.102 & -0.231 & -0.091 & $-0.333 a$ & $-0.311 \mathrm{a}$ \\
\hline jp & 0.031 & $-1.027 \mathrm{a}$ & -0.157 & -0.165 & $0.888 \mathrm{a}$ & $-1.320 \mathrm{a}$ & $-0.163 c$ & $-0.173 c$ \\
\hline $\mathbf{k r}$ & $0.287 \mathrm{~b}$ & $-1.739 a$ & $-0.269 \mathrm{a}$ & $-0.289 a$ & 0.225 & $-2.045 \mathrm{a}$ & $-0.280 \mathrm{a}$ & $-0.294 \mathrm{a}$ \\
\hline my & -0.197 & $0.411 \mathrm{~b}$ & -0.029 & -0.026 & -0.693 & $-2.040 \mathrm{a}$ & $-0.364 \mathrm{a}$ & $-0.364 a$ \\
\hline th & $0.818 \mathrm{a}$ & $-0.414 \mathrm{a}$ & $0.398 \mathrm{a}$ & $0.382 \mathrm{a}$ & -0.079 & -0.152 & $-0.311 \mathrm{a}$ & $-0.295 \mathrm{a}$ \\
\hline const & & 4.449 & -5.189 & 0.174 & & $15.092 \mathrm{~b}$ & 0.375 & 7.367 \\
\hline
\end{tabular}


M. B. Zolin, U. Uprasen

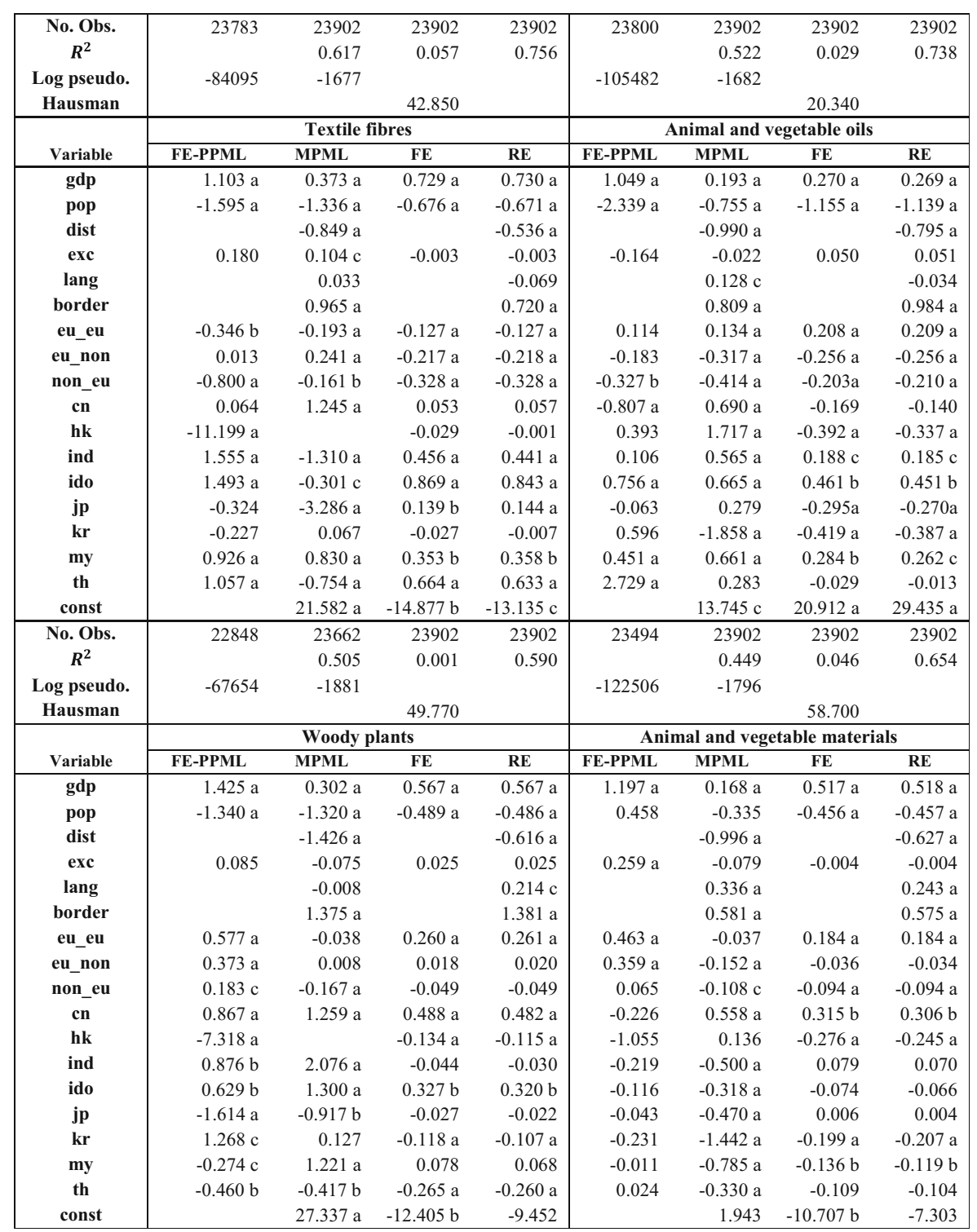


Trade creation and diversion: effects of EU enlargement on...

\begin{tabular}{|c|c|c|c|c|c|c|c|c|}
\hline $\begin{array}{c}\text { No. Obs. } \\
R^{2}\end{array}$ & 22899 & 23662 & 23902 & 23902 & 23460 & 23902 & 23902 & 23902 \\
\hline Loo nseudo & -63834 & $\begin{array}{r}0.144 \\
1502\end{array}$ & 0.007 & 0.002 & 41431 & -1849 & & \\
\hline Hausman & -05034 & -1J72 & 28.230 & & -41451 & & 61.650 & \\
\hline \multirow[b]{2}{*}{ Variable } & \multicolumn{4}{|c|}{ Total agricultural products } & & & & \\
\hline & FE-PPML & MPML & FE & RE & & & & \\
\hline gdp & $1.061 \mathrm{a}$ & $0.327 \mathrm{a}$ & $0.909 \mathrm{a}$ & $0.908 \mathrm{a}$ & & & & \\
\hline pop & $-0.951 b$ & $-1.017 \mathrm{a}$ & $-1.423 \mathrm{a}$ & $-1.423 \mathrm{a}$ & & & & \\
\hline dist & & $-0.939 a$ & & $-1.256 \mathrm{a}$ & & & & \\
\hline exc & $0.092 \mathrm{c}$ & -0.039 & $0.081 \mathrm{a}$ & $0.081 \mathrm{a}$ & & & & \\
\hline lang & & $0.257 \mathrm{a}$ & & $0.375 \mathrm{a}$ & & & & \\
\hline border & & $0.799 \mathrm{a}$ & & $0.743 \mathrm{a}$ & & & & \\
\hline eu_eu & $0.301 \mathrm{a}$ & 0.020 & $0.255 \mathrm{a}$ & $0.254 \mathrm{a}$ & & & & \\
\hline eu_non & $0.215 \mathrm{a}$ & $-0.290 \mathrm{a}$ & -0.045 & -0.053 & & & & \\
\hline non_eu & 0.059 & $-0.328 \mathrm{a}$ & $-0.197 \mathrm{a}$ & $-0.207 \mathrm{a}$ & & & & \\
\hline cn & -0.151 & 0.117 & 0.041 & 0.049 & & & & \\
\hline hk & $-0.693 a$ & 0.052 & $-0.714 \mathrm{a}$ & $-0.679 a$ & & & & \\
\hline ind & -0.029 & 0.086 & -0.036 & -0.030 & & & & \\
\hline ido & $0.398 \mathrm{a}$ & 0.170 & $0.229 \mathrm{c}$ & $0.229 \mathrm{c}$ & & & & \\
\hline jp & -0.022 & $-1.124 \mathrm{a}$ & -0.170 & -0.176 & & & & \\
\hline kr & $-0.236 \mathrm{c}$ & $-1.009 a$ & $-0.355 \mathrm{a}$ & $-0.356 a$ & & & & \\
\hline my & 0.062 & $0.424 \mathrm{a}$ & 0.042 & 0.051 & & & & \\
\hline th & 0.046 & $-0.178 b$ & 0.034 & 0.035 & & & & \\
\hline const & & $16.743 \mathrm{a}$ & 0.571 & 8.917 & & & & \\
\hline No. Obs. & 23885 & 23902 & 23902 & 23902 & & & & \\
\hline$R^{2}$ & & 0.750 & 0.003 & 0.843 & & & & \\
\hline $\begin{array}{c}\text { Log pseudo. } \\
\text { Hausman }\end{array}$ & -315226 & -1772 & 45.930 & & & & & \\
\hline
\end{tabular}

FE-PPML fixed effects Poisson pseudo-maximum likelihood, $M P M L$ multinomial Poisson maximum likelihood, $F E$ fixed effects (within) regression, $R E$ random effects GLS regression

$g d p \ln \left(\mathrm{gdp}_{\mathrm{et}} * \mathrm{gdp}_{\mathrm{it}}\right)$, pop $\ln \left(\mathrm{pop}_{\mathrm{et}} * \mathrm{pop}_{\mathrm{it}}\right)$, dist $\operatorname{lndist} \mathrm{e}_{\mathrm{e}}$, exc $\ln \mathrm{exc}_{\mathrm{eit}}$, lang $d$ lang $_{\mathrm{ei}}$, border border $\mathrm{e}_{\mathrm{ei}}$,

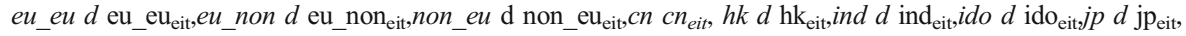
$k r \bar{d} \mathrm{kr}_{\mathrm{eit}}, m \bar{y} d \mathrm{my}_{\mathrm{eit}}$, th $\mathrm{d}$ the $\mathrm{eit}_{\mathrm{t}}$, const constant

Obs. number of observations, $R^{2}$ goodness of fit of the model, $\log$ pseudo Log pseudolikelihood, Hausman Hausman test $\left(\chi^{2}\right)$

Statistical significance is denoted as a (1\%), b (5\%) and c (10\%). Standard errors are in parentheses 


\section{Appendix 2}

Table 5 The export share of agricultural and food products from selected Asian countries to the EU market vis-à-vis the world market (per cent)

\begin{tabular}{|c|c|c|c|c|c|c|c|c|c|}
\hline Product & $\begin{array}{l}\text { Export } \\
\text { share }\end{array}$ & China & Hong Kong & India & Indonesia & Japan & Korea & Malaysia & Thailand \\
\hline \multirow[t]{2}{*}{ Live animals } & Before & & 0.05 & & 13.11 & & & & \\
\hline & After & & 0.25 & & 11.03 & & & & \\
\hline \multirow[t]{2}{*}{ Seafood } & Before & & 7.71 & & & & 6.06 & 32.58 & \\
\hline & After & & 7.81 & & & & 6.34 & 10.12 & \\
\hline \multirow[t]{2}{*}{ Cereals } & Before & & 13.77 & & 5.70 & 2.35 & 1.69 & & \\
\hline & After & & 4.50 & & 2.00 & 2.92 & 2.54 & & \\
\hline \multirow[t]{2}{*}{ Vegetables and fruits } & Before & & 21.73 & 26.23 & & & 0.46 & 6.39 & 32.31 \\
\hline & After & & 10.55 & 21.63 & & & 2.51 & 5.39 & 13.66 \\
\hline \multirow[t]{2}{*}{ Sugars } & Before & & 4.19 & & & & 2.08 & & 2.14 \\
\hline & After & & 2.09 & & & & 0.88 & & 2.79 \\
\hline \multirow[t]{2}{*}{ Colonial products } & Before & & 6.94 & 31.00 & 22.27 & & & 19.38 & \\
\hline & After & & 6.10 & 25.79 & 18.67 & & & 10.35 & \\
\hline \multirow[t]{2}{*}{ Feedstuffs } & Before & 6.86 & 19.71 & & 18.94 & & 3.04 & & 9.01 \\
\hline & After & 10.25 & 18.30 & & 14.03 & & 3.10 & & 12.22 \\
\hline \multirow{2}{*}{$\begin{array}{l}\text { Beverages and } \\
\text { tobacco }\end{array}$} & Before & & 1.00 & & & 1.89 & & & \\
\hline & After & & 0.55 & & & 3.98 & & & \\
\hline \multirow[t]{2}{*}{ Textile fibres } & Before & & 0.96 & 20.12 & 15.47 & & & 35.84 & 10.76 \\
\hline & After & & 0.00 & 3.20 & 14.05 & & & 26.38 & 8.36 \\
\hline \multirow{2}{*}{$\begin{array}{l}\text { Animal and } \\
\text { Vegetable oils }\end{array}$} & Before & 24.37 & & & 27.41 & & & 14.04 & 1.67 \\
\hline & After & 19.88 & & & 17.10 & & & 13.14 & 14.20 \\
\hline \multirow[t]{2}{*}{ Woody plants } & Before & 4.96 & 0.01 & 43.71 & 12.77 & 19.13 & 0.42 & 17.87 & 12.37 \\
\hline & After & 15.89 & 0.00 & 22.08 & 21.88 & 1.06 & 1.76 & 16.18 & 2.84 \\
\hline \multirow{2}{*}{$\begin{array}{l}\text { Animal and } \\
\text { vegetable mat. }\end{array}$} & Before & & & & & & & & \\
\hline & After & & & & & & & & \\
\hline \multirow{2}{*}{$\begin{array}{l}\text { Total agricultural } \\
\text { products }\end{array}$} & Before & & 9.90 & & 18.86 & & 3.80 & & \\
\hline & After & & 6.11 & & 15.61 & & 3.46 & & \\
\hline
\end{tabular}

Source: Author's calculations based on data from the UN's Comtrade databases

Before $=1999-2003$, after $=2004-2015$. Only the significantly affected industries are reported 


\section{Appendix 3}

Table 6 The EU major trade partners in agricultural and food products (1999-2015)

\begin{tabular}{|c|c|c|c|c|c|}
\hline \multirow[t]{2}{*}{ EU country } & \multicolumn{2}{|c|}{$\begin{array}{l}\text { Intra-EU total trade in } \\
\text { agricultural and food }\end{array}$} & \multirow[t]{2}{*}{ EU's trade partner } & \multicolumn{2}{|c|}{$\begin{array}{c}\text { Extra-EU total trade in } \\
\text { agricultural and food }\end{array}$} \\
\hline & in $10^{11}$ EURO & Per cent & & in $10^{11}$ EURO & Per cent \\
\hline Germany & 18.22 & 17.98 & The United States & 4.77 & 11.92 \\
\hline The Netherlands & 13.23 & 13.05 & Brazil & 3.03 & 7.58 \\
\hline France & 12.36 & 12.20 & The Russian Federation & 2.04 & 5.10 \\
\hline Italy & 8.17 & 8.06 & Switzerland & 1.70 & 4.25 \\
\hline The United Kingdom & 8.02 & 7.91 & Norway & 1.43 & 3.57 \\
\hline Belgium & 8.00 & 7.90 & Turkey & 1.35 & 3.38 \\
\hline Spain & 6.94 & 6.85 & Canada & 1.31 & 3.26 \\
\hline Poland & 3.02 & 2.98 & Argentina & 1.08 & 2.70 \\
\hline Austria & 3.02 & 2.98 & Australia & 0.84 & 2.10 \\
\hline Denmark & 2.97 & 2.93 & South Africa & 0.82 & 2.04 \\
\hline Sweden & 2.59 & 2.56 & Total 10 major partners & 18.37 & 45.91 \\
\hline Ireland & 2.44 & 2.41 & China & 2.18 & 5.44 \\
\hline Portugal & 1.74 & 1.72 & Japan & 1.07 & 2.66 \\
\hline The Czech Republic & 1.68 & 1.66 & Indonesia & 0.81 & 2.04 \\
\hline Greece & 1.33 & 1.31 & India & 0.70 & 1.75 \\
\hline Hungary & 1.32 & 1.30 & Thailand & 0.58 & 1.45 \\
\hline Finland & 1.22 & 1.20 & Malaysia & 0.48 & 1.20 \\
\hline the Slovak Republic & 0.83 & 0.82 & Hong Kong & 0.48 & 1.19 \\
\hline Romania & 0.78 & 0.77 & South Korea & 0.41 & 1.03 \\
\hline Bulgaria & 0.50 & 0.50 & Total 8 Asian countries & 6.70 & 16.76 \\
\hline 20 selected EU countries & 98.38 & 97.09 & 18 selected countries & 25.07 & 62.67 \\
\hline Rest of EU & 2.95 & 2.91 & Rest of the world & 14.94 & 37.33 \\
\hline Total intra-EU trade & 101.33 & 100.00 & Total extra-EU trade & 40.01 & 100.00 \\
\hline
\end{tabular}

Source: Author's calculations based on data from the UN's Comtrade databases

\section{References}

Abbassi A, Bonroy O, Gervais JP (2008) Dairy trade liberalization impacts in Canada. CJAE 56(3):313-335. https://doi.org/10.1111/j.1744-7976.2008.00131.x

Abler D, Banse M, Kulper M, Roza P, Santuccio F (2009) EU Agricultural trade relations with Asian countries, JRC Scientific and Technical Reports, European Commission

Anderson JE (1979) A theoretical foundation for the gravity equation. AER 69(1):106-116

Anderson JE, Wincoop EV (2003) Gravity with gravitas: a solution to the border puzzle. AER 93(1):170-192

Auboin M, Ruta M (2011) The relationship between exchange rates and international trade: a review of economic literature, Staff Working Paper ERSD-2011-17, WTO

Bach CF, Frandsen SE, Jensen HG (2000) Agricultural and economy - wide effects of European enlargement: modelling the common agricultural policy. JAE 51(2):162-180. https://doi.org/10.1111/j.14779552.2000.tb01221.x

Banse M (2000) Macroeconomic implications of the EU accession. In: Tangerman S, Banse M (eds) Central and Eastern European agriculture in an Expanding European Union, CAB International

Banse M, Munch W, Tangermann S (2000) Eastern enlargement of the European Union: a general and partial equilibrium analysis. Contributed paper at XXI International Conference of Agricultural Economics (IAAE), Berlin

Bartošová D, Bartová L, Fidrmuc J (2007) Implications of EU enlargement for the new member states, Agrifood Trade Working Paper. 07/10, TRADEAG 
Bergstrand JH (1985) The gravity equation in international trade: some microeconomic foundations and empirical evidence. REStat 67(3):474-481

Bergstrand JH (1989) The generalized gravity equation, monopolistic competition, and the factor-proportions theory. International Trade. REStat 71(1):143-153

Carrère C (2006) Revisiting the effects of regional trade agreements on trade flows with proper specification of the gravity model. EER 50(2):223-247. https://doi.org/10.1016/j.euroecorev.2004.06.001

ChinaAg Consulting (2018) Gateway to China: Hong Kong re-exports of agricultural good. http://www. chinaag.org/2015/06/30/gateway-to-china-hong-kong-re-exports-of-agricultural-goods/. Accessed 20 Feb 2018

Dai M, Yotov YV, Zylkin T (2014) On the trade-diversion effects of free trade agreements. Econ Lett 122(2): 321-325. https://doi.org/10.1016/j.econlet.2013.12.024

Deardorff AV (1998) Determinants of bilateral trade: does gravity work in a neoclassical world? In: Frankel JA (ed) The regionalization of the world economy, The University of Chicago Press, Chapter URL: http://www.nber.org/chapters/c7818 pp 7-32. Accessed 20 Feb 2017

Devadoss S, Sridharan P, Wahl T (2009) Effects of trade barriers on U.S. and World Apple Markets. CJAE 57(1):55-73. https://doi.org/10.1111/j.1744-7976.2008.01138.x

Drabik D, Pokrivcak J, Ciaian P (2007) Trade creation and diversion in the enlarged EU market: evidence for agricultural trade in Slovakia. Czech J Econ Financ 57(9-10):433-447

Enke S (1951) Equilibrium among spatially separated markets: solution by electric analogue. Econometrica 19(1):40-47

European Commission (2011) The CAP in perspective: from market intervention to policy innovation, Agricultural Policy Perspectives Brief

Frandsen SE, Gersfelt B, Jensen HG (2003) The impacts of redesigning European agricultural support. Rev Urban Reg Dev Stud 15(2):106-131. https://doi.org/10.1111/1467-940X.00068

Frankel JA (1997) Regional trading blocs in the world economic system. Institute for International Economics, Washington, DC

Grant W (1997) The common agricultural policy. Macmillan Press Ltd., Basingstoke

Head K, Mayer T (2014) Gravity equations: workhorse, toolkit, and cookbook. In: Gopinath G, Helpman E, Rogoff K (eds) Handbook of international economics, vol 4. Elsevier, Amsterdam

Herok A, Lotze H (2000) Implications of an EU eastern enlargement under a new common agricultural policy. J Policy Model 22(6):661-690. https://doi.org/10.1016/S0161-8938(98)00035-0

Indexmundi (2018) Agriculture, Thailand palm oil production by year. https://www.indexmundi. com/agriculture/?country=th\&commodity=palm-oil\&graph=production. Accessed 15 Feb 2018

Isard W (1954) Location theory and trade theory: short-run analysis. QJE 68:305-322

Kahouli B, Maktouf S (2015) Trade creation and diversion effects in Mediterranean area: econometric analysis by gravity model. J Int Trade Econ Dev 24(1):76-104. https://doi.org/10.1080/09638199.2013.873479

Krugman P (1991) Is bilateralism bad? In: Helpman E, Razin A (eds) International Trade and Trade Policy. The MIT Press, Cambridge, London

Lin L (2006) Spatial equilibrium model on regional analysis for the trade liberalization of fluid milk in Taiwan. In: Gabrys B, Howlett RJ, Jain L (eds) Knowledge-based intelligent information and engineering systems. KES 2006. Lecture Notes in Computer Science, vol 4253. Springer, Berlin, Heidelberg

Magee C (2008) New measures of trade creation and trade diversion. JIE 75(2):349-362. https://doi. org/10.1016/j.jinteco.2008.03.006

Martínez-Zarzoso I, Nowak-Lehmann DF, Horsewood N (2009) Are regional trading agreements beneficial? Static and dynamic panel gravity models. N Am J Econ Financ 20(1):46-65. https://doi.org/10.1016/j. najef.2008.10.001

Rosillo-Calle F, Pelkmans L, Walter A (2009) A global overview of vegetable oils, with reference to biodiesel, Report, IEA task 40, https://www.google.it/search?q=A+GLOBAL+OVERVIEW+OF+VEGETABLE +OILS\%2C+WITH+REFERENCE+TO+BIODIESEL+A+Report+for+the+IEA+Bioenergy+Task+40 $\& o q=\mathrm{A}+\mathrm{GLOBAL}+\mathrm{OVERVIEW}+\mathrm{OF}+\mathrm{VEGETABLE}+\mathrm{OILS} \% 2 \mathrm{C}+\mathrm{WITH}+\mathrm{REFERENCE}+\mathrm{TO}$ +BIODIESEL+A+Report+for+the+IEA+Bioenergy+Task+40\&aqs=chrome..69i57j69i6412.2196j0j7 \&sourceid=chrome\&ie=UTF-8. Accessed $20 \mathrm{Feb} 2018$

Samuelson PA (1952) Spatial price equilibrium and linear programming. AER 42(3):83-303

Santos Silva JM, Tenrero S (2009) Comments on the log of gravity revisited, Manuscript, London School of Economics

Santos Silva JMC, Tenreyo S (2006) The log of gravity. REStat 88(4):641-658

Sarker R, Jayasinghe S (2007) Regional trade agreements and trade in agri-food products: evidence for the European Union from gravity modeling using disaggregated data. Agric Econ 37(1):93-104. https://doi. org/10.1111/j.1574-0862.2007.00227.x 
Sun L, Reed MR (2010) Impacts of free trade agreements on agricultural trade creation and trade diversion. Am J Agric Econ 92(5):1351-1363

Swinnen JFM (1996) Endogenous price and trade policy development in Central European agriculture. Eur Rev Agric Econ 23(2):133-160

Takayama T, Judge GG (1971) Spatial and temporal price and allocation models. North-Holland Pub. Co, Amsterdam

Tangermann S (1995) Eastward enlargement of the EU: will agricultural policy be an obstacle?, Intereconomics, ISSN 0020-5346, Nomos Verlagsgesellschaft, Baden-Baden, 30, Iss 6:277284.

Tangermann S, Josling TE (1994) Pre-accession agricultural policies for Central Europe and the European Union, Study commissioned by DGI of the European Commission, Brussels

Tinbergen J (1962). Shaping the world economy: suggestions for an international economic policy, Appendix VI. : The Twentieth Century Fund, New York

Urata S, Okabe M (2014) Trade creation and diversion effects of regional trade agreements: a product-level analysis. World Econ 37(2):267-289. https://doi.org/10.1111/twec.12099

Viner J (1950) Customs union theory. Carnegie Endowment for International Peace, New York

World Bank (2016) Vietnam development report 2016 transforming Vietnamese agriculture: gaining more from less. Available at http://pubdocs.worldbank.org/en/981291474945431360/pdf/VDR2016-brief-EN. pdf. Accessed 26 June 2017

Yang S, Martinez-Zarzoso I (2014) A panel data analysis of trade creation and trade diversion effects: the case of ASEAN-China Free Trade Area. China Econ Rev 29:138-151. https://doi.org/10.1016/j. chieco.2014.04.002 